5-15-1999

\title{
SeaWiFS satellite ocean color data from the Southern Ocean
}

JK Moore

MR Abbott

RG Richman

Walker O. Smith Jr.

College of William and Mary

et al

Follow this and additional works at: https://scholarworks.wm.edu/vimsarticles

Part of the Oceanography Commons

\section{Recommended Citation}

Moore, JK; Abbott, MR; Richman, RG; Smith, Walker O. Jr.; and al, et, "SeaWiFS satellite ocean color data from the Southern Ocean" (1999). VIMS Articles. 1407.

https://scholarworks.wm.edu/vimsarticles/1407

This Article is brought to you for free and open access by the Virginia Institute of Marine Science at W\&M ScholarWorks. It has been accepted for inclusion in VIMS Articles by an authorized administrator of W\&M ScholarWorks. For more information, please contact scholarworks@wm.edu. 


\title{
SeaWiFS satellite ocean color data from the Southern Ocean
}

\author{
J. Keith Moore ${ }^{1}$, Mark R. Abbott' ${ }^{1}$ James G. Richman', Walker O. Smith ${ }^{2}$, Timothy \\ J. Cowles ${ }^{1}$, Kenneth H. Coale ${ }^{3}$, Wilford D. Gardner ${ }^{4}$, Richard T. Barber
}

\begin{abstract}
SeaWiFS estimates of surface chlorophyll concentrations are reported for the region of the U.S. JGOFS study in the Southern Ocean $\left(\sim 170^{\circ} \mathrm{W}, 60^{\circ} \mathrm{S}\right)$. Elevated chlorophyll was observed at the Southern Ocean fronts, near the edge of the seasonal ice sheet, and above the PacificAntarctic Ridge. The elevated chlorophyll levels associated with the Pacific-Antarctic Ridge are surprising since even the crest of the ridge is at depths $>2000 \mathrm{~m}$. This elevated phytoplankton biomass is likely the result of mesoscale physical-biological interactions where the Antarctic Circumpolar Current (ACC) encounters the ridge. Four cruises surveyed this region between October 1997 and March 1998, as part of the U.S. JGOFS. Satellite-derived chlorophyll concentrations were compared with in situ extracted chlorophyll measurements from these cruises. There was good agreement $\left(r^{2}\right.$ of 0.72 , from a linear regression of shipboard vs. satellite chlorophyll), although SeaWiFS underestimated chlorophyll concentrations relative to the ship data.
\end{abstract}

\section{Introduction}

The U.S. JGOFS (Joint Global Ocean Flux Study) site along $170{ }^{\circ} \mathrm{W}$ is an ambitious effort to improve our understanding of the role ocean biota play in the global carbon cycle and climate system. Four cruises surveyed the region along $170^{\circ} \mathrm{W}$ between October 1997 and March 1998. The Antarctic Polar Front (PF) was the primary focus of these cruises. Two other major Southern Ocean fronts are found in this region. The Subantarctic Front (SAF) is north of the PF, and the Southern Antarctic Circumpolar Current Front (SACCF) is south of the PF [Orsi et al., 1995]. Studies were carried out to evaluate carbon fluxes and their critical controlling processes. Here we present SeaWiFS (Seaviewing Wide Field-of-view Sensor) surface chlorophyll data for the JGOFS region, which provides a larger spatial context for interpreting the shipboard observations.

\footnotetext{
${ }^{1}$ College of Oceanic and Atmospheric Sciences, Oregon State University

${ }^{2}$ Virginia Institute of Marine Sciences

${ }^{3}$ Moss Landing Marine Laboratories

${ }^{4}$ Texas A \& M University, Department of Oceanography

${ }^{5}$ Duke University, NSOE Marine Laboratory
}

Copyright 1999 by the American Geophysical Union.

Paper number 1999GL900242.

0094-8276/99/1999GL900242\$05.00

\section{Results}

The mean SeaWiFS-derived surface chlorophyll concentrations (composite averages of the version 2, Level 3 daily files obtained from NASA) during the JGOFS cruises are shown in Figure 1 (areas in black had no chlorophyll data due to cloud or ice cover). Figure 1E shows the topography of the region [Smith and Sandwell, 1994], the mean path of the PF [Moore et al., 1999], and the mean paths of the SAF and SACCF [Orsi et al., 1995]. The Pacific-Antarctic Ridge dominates the topography of the region. Elevated chlorophyll levels are seen primarily in three areas: near the receding ice edge, at the major fronts, and above the Pacific-Antarctic Ridge. A seasonal progression of phytoplankton biomass is also apparent, with low chlorophyll concentrations during early austral spring (Figure 1A), a bloom period (Figure 1B \& $1 C)$, and low values during fall (Figure 1D).

Remarkable in Figure 1 are the elevated chlorophyll concentrations above the Pacific-Antarctic Ridge relative to surrounding waters. This pattern was extremely consistent, evident to some extent during each cruise. This topographic effect is surprising since the crest of the ridge is at depths of $2000 \mathrm{~m}$ or more (Figure 1E). These phytoplankton blooms may be caused by mesoscale physical-biological interactions where the ACC encounters the ridge. Two physical processes, meander-induced upwelling at the Southern Ocean fronts and increased eddy activity, are likely to increase nutrient input from below the surface layer (including micronutrients) at the ridge.

Mesoscale meandering of the PF increases where it encounters large topographic features [Moore et al., 1999]. Surface drifters released in January 1998 indicate that mesoscale meandering is intensified near the ridge (Figure 2). Note that the tracks closest to the ridge crest have sharp turns and meanders with wavelengths of $\sim 50-100 \mathrm{~km}$, while the tracks farthest from the ridge crest exhibit broad, slow, meandering with wavelengths of $\sim 300-500 \mathrm{~km}$. Mesoscale meandering causes localized areas of upwelling/downwelling, which in turn can have strong effects on ocean biota [Flierl and Davis, 1993].

Large amounts of relative vorticity are input to the water column where ocean depth changes rapidly, such as along the Pacific-Antarctic Ridge, through the shrinking/stretching of vortex lines. This relative vorticity is likely dissipated through nonlinear processes such as eddy actions. Elevated eddy mixing would increase nutrient flux to the surface layer, including micronutrients such as iron, from sub-surface waters. This increased eddy mixing would occur both within the PF and the SACCF, and in open ocean waters away from the fronts. Phytoplankton blooms were observed along the Pacific-Antarctic Ridge with the Coastal Zone Color Scanner [Sullivan et al., 1993]. We have observed similar 


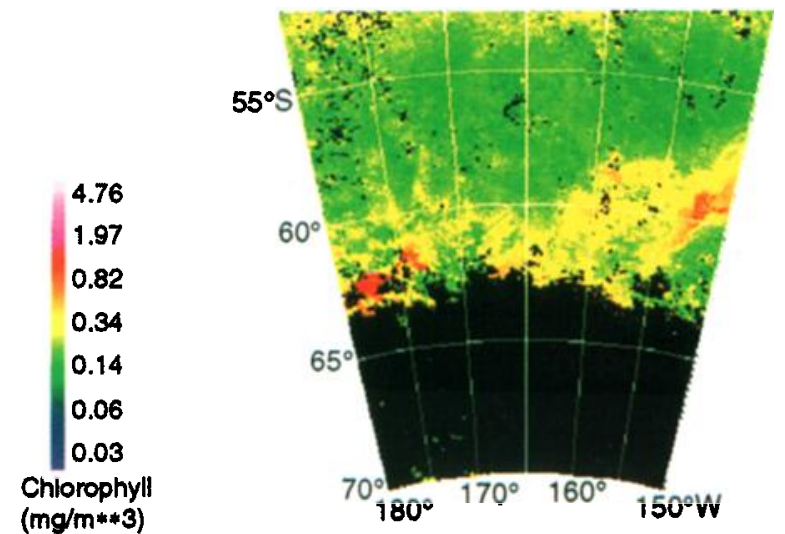

A. Survey I (10/20-11/22)

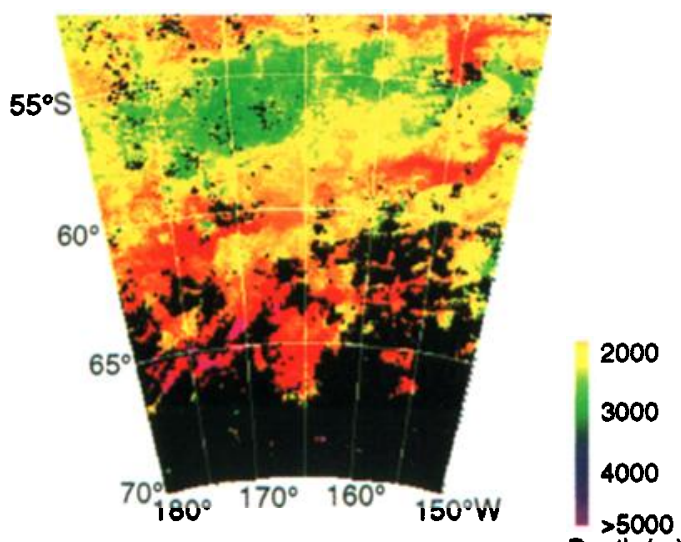

B. Process I (12/3-1/3) Depth (m)

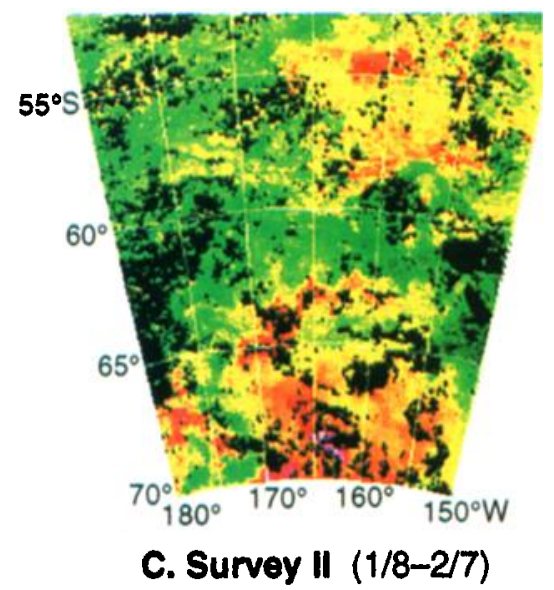

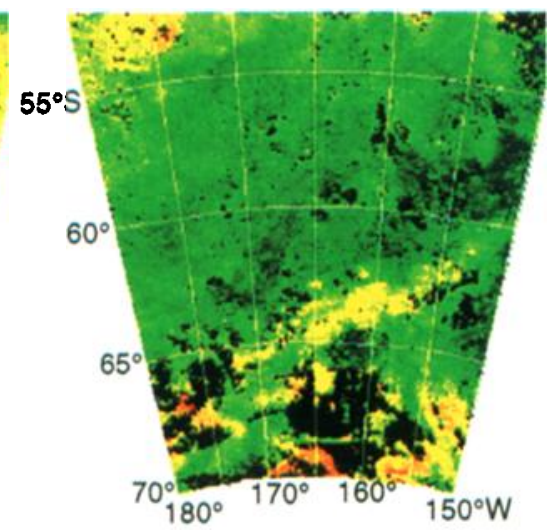

D. Process II (2/14-3/18)

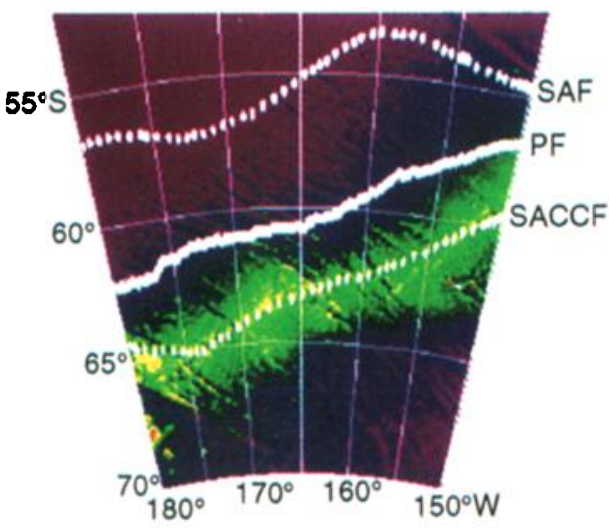

E. Topography

Figure 1. Mean surface chlorophyll concentration for each of the four JGOFS cruises are displayed (1A, 1B, 1C, and 1D). Also shown is the topography of the region [Smith and Sandwell, 1994], the mean path of the Antarctic Polar Front (PF) [Moore et al., 1999], and the mean paths of the Subantarctic Front (SAF) and the Southern Antarctic Circumpolar Current Front (SACCF) [Orsi et al., 1995] (1E).

increases in chlorophyll concentration in SeaWiFS imagery where the ACC encounters other large topographic features, such as Kerguelen Plateau, the North Scotia Ridge, and the Southeast Indian Ridge.

During the Survey I cruise (10/20-11/22/97), the sea ice extended to $\sim 63{ }^{\circ} \mathrm{S}$ (Figure 1A). The mean SeaWiFSderived chlorophyll concentration during this cruise over the region was $0.24 \mathrm{mg} / \mathrm{m}^{3}$ (the region is defined as the area from $180-150^{\circ} \mathrm{W}$ by $55-70^{\circ} \mathrm{S}$ ). Along $170^{\circ} \mathrm{W}$, the mean SeaWiFS chlorophyll concentration was $0.21 \mathrm{mg} / \mathrm{m}^{3}$ (mean values for along $170^{\circ} \mathrm{W}$ include the area $170.5-169.5^{\circ} \mathrm{W}$ by $55-70^{\circ} \mathrm{S}$ ). Higher chlorophyll values are seen near the ice edge, in the vicinity of the PF, and above the Pacific-Antarctic Ridge from $\sim 155-150^{\circ} \mathrm{W}$ (Figure $1 \mathrm{~A} \&$ IE). The high chlorophyll concentrations ( $>1.0 \mathrm{mg} / \mathrm{m}^{3}$ ) just west of the JGOFS line from $\sim 180-173^{\circ} \mathrm{W}$ did not appear until the last week of the cruise period. Mixed layer depths were generally quite deep (at times $>150 \mathrm{~m}$ ). Towards the end of the cruise, mixed layers depths of 60-80 $\mathrm{m}$ were observed.

By the time of the Process I cruise (12/3/97-1/3/98), the sea ice had retreated and a bloom was present at the PF across the whole region (Figure IB \& IE). Mean chlorophyll concentration for the region had increased to $0.48 \mathrm{mg} / \mathrm{m}^{3}$, and along $170^{\circ} \mathrm{W}$ to $0.50 \mathrm{mg} / \mathrm{m}^{3}$. Elevated chlorophyll values north of $55^{\circ} \mathrm{S}$ were in the approximate location of the SAF (Figure 1B \& 1E). A large phytoplankton bloom near the retreating ice edge was visible from $\sim 180-165^{\circ} \mathrm{W}$ (Figure 1B). This bloom was situated in the vicinity of the SACCF above the Pacific-Antarctic Ridge and may be the result of the combined influences of topography and sea ice retreat (Figure 1B \& 1E). The retreating ice edge provides micronutrients such as iron (in dust accumulated over the winter) to the water column [Martin, 1990; Sedwick and DiTullio, 1997] and improves the irradiance-mixing regime for phytoplankton [Smith and Nelson, 1985]. This cruise was marked by shallow mixed layers $(<30 \mathrm{~m})$ with low salinity surface water.

During the Survey II cruise (1/8-2/7/98), the sea ice had retreated below 70 'S (Figure 1C). Regional mean chlorophyll concentration had declined to $0.32 \mathrm{mg} / \mathrm{m}^{3}$, and along $170^{\circ} \mathrm{W}$ was $0.36 \mathrm{mg} / \mathrm{m}^{3}$. Elevated chlorophyll in the vicinity of the PF and the SAF was seen east of the JGOFS study site between $\sim 165-150{ }^{\circ} \mathrm{W}$ (Figure 1C). A phytoplankton bloom was visible from $\sim 170-167^{\circ} \mathrm{W}$ between $-63-65^{\circ} \mathrm{S}$. This bloom was sampled during the Survey II cruise. It was located directly above the Pacific-Antarctic Ridge (Figure IC \& IE) and was not continuous with the blooms farther south, which are likely associated with the retreating ice edge. This bloom appears to be a continuation 
of the bloom initiated during the Process I cruise; it had dissipated by the first week of February. Mixed layer depths remained shallow during this cruise.

During the Process II cruise (2/14-3/18/98), regional mean chlorophyll concentration had declined to $0.19 \mathrm{mg} / \mathrm{m}^{3}$, and along $170^{\circ} \mathrm{W}$ to $0.18 \mathrm{mg} / \mathrm{m}^{3}$ (Figure 1D). Elevated chlorophyll values were again seen above the PacificAntarctic Ridge (Figure 1D \& 1E). This was a persistent pattern, seen in all weekly images over the cruise period. Mixed layer depths were generally deeper than during the preceding cruises, often exceeding $80 \mathrm{~m}$ depth north of the $\mathrm{PF}$, with some values south of the $\mathrm{PF}<50 \mathrm{~m}$.

Shipboard extracted chlorophyll measurements were compared with co-located satellite data collected within 24 hours of the ship sample. Both underway and station shipboard chlorophyll samples were used. For station data where samples from different depths were available, we estimated optical depth with a chlorophyll-based approximation of $K_{\text {par }}$ [Morel, 1988]. Shipboard samples from the upper two optical depths of the water column were averaged for comparison with satellite data. The ship samples were compared with the version 2 chlorophyll data from NASA. The Level 3 standard mapped images $(9-\mathrm{km}$ resolution) and Local Area Coverage (LAC, 1-km resolution) files were used. The LAC data was processed using the global chlorophyll algorithm and the SEADAS software.

The comparison of satellite-derived chlorophyll concentrations with the shipboard chlorophyll measurements reveals generally good agreement (Figure 3). SeaWiFS tended to underestimate chlorophyll relative to shipboard measurements, as did the previous generation ocean color satellite in this region [Sullivan et al., 1993]. A Model II linear regression of shipboard vs. satellite chlorophyll gives the equation $\mathrm{Chl}_{\text {sat }}=0.52\left(\mathrm{Ch}_{\text {ship }}\right)-0.03$, with $\mathrm{r}^{2}=0.72$ where $\mathrm{n}=84$ (95\% confidence interval for the slope was 0.47 to 0.64 and for the intercept -0.0066 to -0.066 ). The generally good agreement between satellite-derived and shipboard

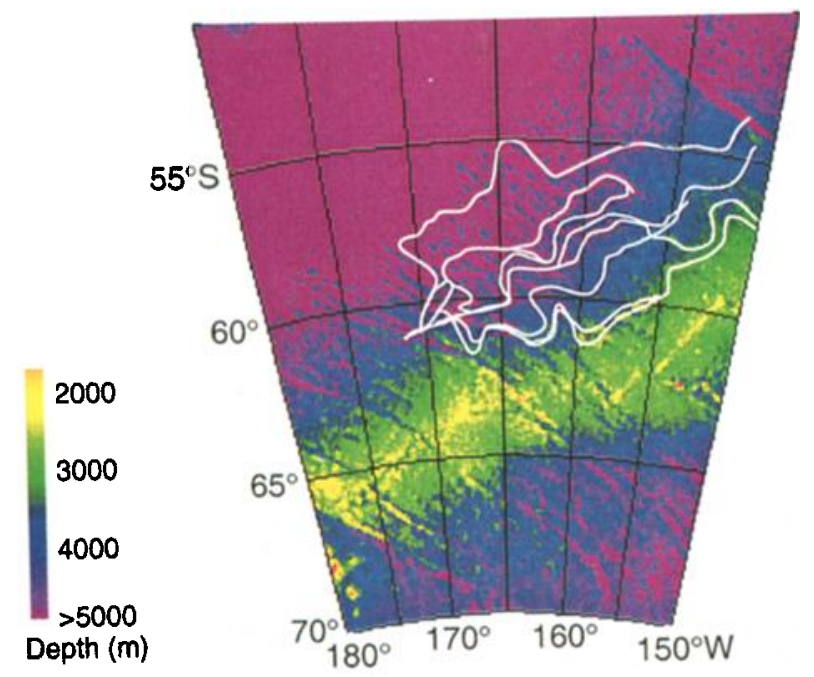

Figure 2. The tracks followed by surface drifters released during January 1998 as part of the Survey II cruise are shown over the topography of the region [topography from Smith and Sandwell, 1994].

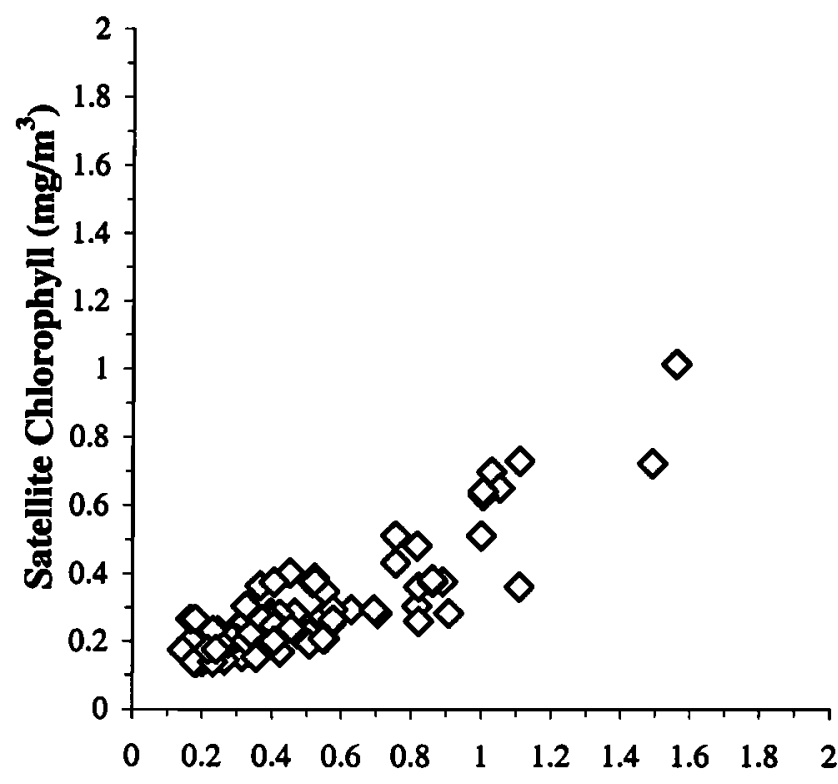

\section{Shipboard Chlorophyll (mg/ $\left.\mathbf{m}^{\mathbf{3}}\right)$}

Figure 3. A comparison of satellite-derived estimates of surface chlorophyll concentration with shipboard measurements of extracted chlorophyll is displayed.

Satellite data was collected within 24 hours of the co-located ship data.

measurements of chlorophyll indicates that SeaWiFS is accurately distinguishing between areas of high and low biomass and, thus, reliably captures the mesoscale features described in this paper.

\section{Conclusions}

There was good agreement between the SeaWiFS surface chlorophyll concentrations along $170^{\circ} \mathrm{W}$ and the regional average during all four JGOFS cruises. Thus the JGOFS line along $170^{\circ} \mathrm{W}$ was broadly representative of this sector of the Southern Ocean. Three areas of elevated chlorophyll concentrations were identified from the satellite imagery: at the receding ice edge, near the Southern Ocean fronts, and above the Pacific-Antarctic Ridge. Each of these high biomass areas was studied intensively at some point during the JGOFS cruises. Synthesis of the JGOFS results with satellite and modeling studies should greatly improve our understanding of the role of marine biota in the carbon cycle of the Southern Ocean and in the larger global climate system.

Acknowledgments. The authors would like to thank the SeaWiFS project (Code 970.2) and the Distributed Active Archive Center (Code 902) at the Goddard Space Flight Center, Greenbelt, MD 20771 , for the production and distribution of these data, respectively. These activities are sponsored by NASA's Earth Science Enterprise Program. The authors would also like to thank the captain and crew of the Revelle and all who participated in the gathering and analysis of the shipboard chlorophyll measurements. This work was supported by a NASA Earth Science Fellowship (J.K.M), NASA Earth Observing System Grant NAG5-4947 (M.R.A.) and NSF Office of Polar Programs Grant 953-0507-OPP (M.R.A.). This is JGOFS contribution number 505 . 


\section{References}

Flierl, G.R. \& C.S. Davis. Biological effects of Gulf Stream meandering. J. Mar. Res. 51, 529-560 (1993).

Martin, J.H. Glacial-Interglacial $\mathrm{CO}_{2}$ change: The Iron Hypothesis. Paleoceanogr. 5, 1-13 (1990).

Moore, J.K., Abbott, M.R., \& J.G. Richman. Location and dynamics of the Antarctic Polar Front from satellite sea surface temperature data. J. Geophys. Res., 104, 3059-3073 (1999).

Morel, A. Optical modeling of the upper ocean in relation to its biogenous matter content (Case I waters). J. Geophys Res.93, $10,749-10,768$ (1988).

Orsi, A.H., Whitworth III, T., \& W.D. Nowlin Jr. On the meridional extent and fronts of the Antarctic Circumpolar Current. Deep Sea Res., Part I, 42, 641-673 (1995).

Sedwick, P.N. \& G.R. DiTullio. Regulation of algal blooms in Antarctic Shelf waters by the release of iron from melting sea ice. Geophys. Res. Lett., 24, 2515-2518.

Smith Jr., W.O., \& D.M. Nelson. Phytoplankton bloom produced by a receding ice edge in the Ross Sea: Spatial coherence with the density field. Science 227, 163-166 (1985).

Smith, W.H.F. \& D.T. Sandwell. Bathymetric prediction from dense satellite altimetry and sparse shipboard bathymetry. $J$ Geophys. Res. 99, 21803-21824 (1994).

Sullivan, C.W., Arrigo, K.R., McClain, C.R., Comiso, J.C, \& J. Firestone. Distributions of Phytoplankton Blooms in the Southern Ocean. Science 262, 1832-1837 (1993).

J.K. Moore, M. Abbott, J. Richman, and T. Cowles, College of Oceanic and Atmospheric Sciences, Oregon State University, 104 Ocean Admin. Building, Corvallis, OR 97331-5503 (email: jmoore@oce.orst.edu, mark@oce.orst.edu).

W. Smith, Virginia Institute of Marine Sciences, Greate Road, Box 1346, Gloucester Pt., VA 23062

K. Coale, Moss Landing Marine Laboratories, P.O. Box 450, Moss Landing, CA 95039-0450

W. Gardner, Texas A \& $M$ University, Department of Oceanography, College Station, TX 77843-3146

R. Barber, Duke University, NSOE Marine Laboratory, 135 Duke Marine Lab Road, Beufort, NC 28516

(Received November 11, 1998; revised February 26,1999; accepted March 22, 1999) 